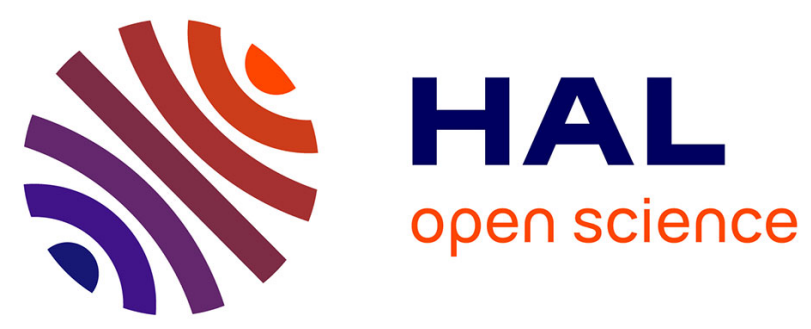

\title{
Enhancement of the biocompatibility by surface nitriding of a low-modulus titanium alloy for dental implant applications
}

Yvan Bedouin, Doina-Margareta Gordin, Pascal Pellen-Mussi, Fabienne Pérez, Sylvie Tricot-Doleux, Cora Vasilescu, Silviu Iulian Drob, Dominique

Chauvel-Lebret, Thierry Gloriant

\section{To cite this version:}

Yvan Bedouin, Doina-Margareta Gordin, Pascal Pellen-Mussi, Fabienne Pérez, Sylvie Tricot-Doleux, et al.. Enhancement of the biocompatibility by surface nitriding of a low-modulus titanium alloy for dental implant applications. Journal of Biomedical Materials Research Part B: Applied Biomaterials, 2019, 107 (5), pp.1483-1490. 10.1002/jbm.b.34240 . hal-01903314

HAL Id: hal-01903314

https://hal-univ-rennes1.archives-ouvertes.fr/hal-01903314

Submitted on 3 Dec 2018

HAL is a multi-disciplinary open access archive for the deposit and dissemination of scientific research documents, whether they are published or not. The documents may come from teaching and research institutions in France or abroad, or from public or private research centers.
L'archive ouverte pluridisciplinaire HAL, est destinée au dépôt et à la diffusion de documents scientifiques de niveau recherche, publiés ou non, émanant des établissements d'enseignement et de recherche français ou étrangers, des laboratoires publics ou privés. 
Enhancement of the biocompatibility by surface nitriding of a low modulus titanium

\section{alloy for dental implant applications}

Y. Bédouin, ${ }^{1,2}$ D.M. Gordin, ${ }^{1}{ }^{*}$ P. Pellen-Mussi, ${ }^{1}$ F. Pérez, ${ }^{3}$ S. Tricot, ${ }^{1}$ C. Vasilescu, ${ }^{4}$ S.I. Drob, ${ }^{4}$ D. Chauvel-Lebret, ${ }^{1,2}$ T. Gloriant ${ }^{1}$

${ }^{1}$ Univ Rennes, INSA Rennes, CNRS, ISCR (Institut des Sciences Chimiques de Rennes) UMR 6226, F-35000 Rennes, France

${ }^{2}$ CHU de Rennes, Pôle d’Odontologie et de Chirurgie Buccale, 2 place Pasteur, 35000

Rennes, France

${ }^{3}$ CHU de Nantes, Service d'Odontologie, 1 Place Alexis Ricordeau, 44000 Nantes, France

${ }^{4}$ Institute of Physical Chemistry "Ilie Murgulescu” of Romanian Academy, Spl.

Independentei 202, 060021 Bucharest, Romania

*Corresponding author : Doina-Margareta Gordin

INSA Rennes

20, avenues des Buttes de Coësmes

35708 Rennes cedex

Tel : +33223238242

E-mail : doina.gordin@insa-rennes.fr 


\begin{abstract}
To enhance their longevity dental implants must be highly biocompatible and must have a low elastic modulus close to that of the bone. They must also possess a high superficial hardness and a high corrosion resistance. For these reasons a recently developed low modulus Ti-27Nb alloy with non-toxic elements was treated by gas nitriding at high temperature in this study. A very thin nitrided layer of $0.5 \mu \mathrm{m}$ in thickness followed by an enriched nitrogen zone was observed. Consequently, a very high hardness evaluated at about $1800 \mathrm{HV}$ was obtained in surface, which represents an increase of 4-5 times the hardness of the non nitrided alloy. This superficial hardness was experimentally observed to decrease up to $800 \mathrm{~nm}$ in depth from the surface to the core. The low modulus of Ti-27Nb (evaluated at $55 \mathrm{GPa}$, which is twice lower than the commercially pure titanium) was not affected by the surface nitriding treatment. A better corrosion resistance was observed as well as a significant decrease in ion release rates for the nitrided alloy (ion release of $1.41 \mathrm{ng} / \mathrm{cm}^{2}$ compared to the $163.58 \mathrm{ng} / \mathrm{cm}^{2}$ obtained for the commercially pure titanium at $\mathrm{pH}=7.48$ in artificial Carter-Brugirard saliva). The cytocompatibility was not compromised and the cell viability performed on human osteoblasts, fibroblastic cells and epithelial cells was enhanced on the nitrided surface in comparison with the non-nitrided surface. These combined properties make the nitrided Ti27Nb alloy a good candidate for dental implant applications.
\end{abstract}

Keywords: titanium alloy, low modulus, surface nitriding, superficial hardness, biocompatibility, corrosion resistance

Running heads: Surface nitriding of low modulus Ti-27Nb alloy for dental implants 


\section{Introduction}

Titanium alloys are widely used as dental implants or prosthesis in medicine. These alloys fulfill many requirements for such applications: high strength, low density, excellent corrosion resistance, high biocompatibility and the ability of osseointegration, which means the capacity to establish a solid and durable connection with the osseous structure. ${ }^{1}$ The implants are now expected to serve for much longer periods or entire lifetime without failure because of the higher life expectancy. The concept of mechanical biocompatibilities is considered as an important factor for the implant's longevity. ${ }^{2,3}$ Among the material properties, the elastic modulus is of significant importance and is currently receiving considerable attention.

Most of the titanium alloys used in medicine are commercially pure titanium (Cp-Ti) and the Ti-6Al-4V alloy that have a higher elastic stiffness and a relatively high elastic modulus (110 GPa) in comparison with cortical bone (30 GPa). It has already been reported that decreasing the elastic modulus of metallic implants minimizes the bone atrophy due to the stress shielding effect and increases the durability of orthopedic implants. ${ }^{4}$ For dental implants, a low modulus induces a better stress transfer along the bone implant interface. This mechanical property could limit the crestal bone loss due to excessive load transmitted to the bone through the crest module.

A drawback of the commonly used Ti-6Al-4V alloy is the presence of toxic $\mathrm{Al}$ and $\mathrm{V}$ oxide types in their surface region, ${ }^{5,6}$ which may be absorbed into the body. This main problem may appear particularly after long-term implantation in the body of an implant fabricated from the Ti-6Al-4V alloy. Great attention has therefore been paid to the development of new titanium alloys without $\mathrm{Al}$ and $\mathrm{V}$, which have low modulus and fulfil the fundamental requirements for their applicability as implants. ${ }^{7}$ For example, metastable beta Ti-based alloys which contain non-toxic elements such as $\mathrm{Nb}$, $\mathrm{Ta}$, Mo and $\mathrm{Zr}$ are under extensive investigation for 
biomedical applications. ${ }^{3,8,9}$ With this alloy system, adjusted chemical compositions can display a reversible stress-induced martensitic transformation that leads to a superelastic effect (high recoverable strain) and a very significant reduction of the apparent elastic modulus. ${ }^{10}$ In this context, the niobium element is promising as a non-toxic and $\beta$-stabilizing element. In literature, alloys from the Ti-Nb system have been particularly investigated ${ }^{11}$ and reported to be non-cytotoxic.

Another key point to take into consideration for implant's longevity is the potential detrimental effects of wear debris ${ }^{12}$ and metal ion being released due to corrosion. ${ }^{13-15}$ The wear debris has been associated with cytotoxicity, inhibition of cell differentiation, phagocytosis of metallic particles by macrophages, inflammation and neoplasic changes. ${ }^{12}$ Consequently, high superficial hardness can be very useful to avoid the release of metal debris in the surrounding tissues that can affect the biocompatibility. ${ }^{16,17}$ Nitrided titanium surfaces have also been reported to present antimicrobial properties ${ }^{18}$ and several in vitro and in vivo studies have demonstrated their good biological performance. ${ }^{19-21}$

The aim of the present study was to apply a surface nitriding treatment on a recently developed low modulus Ti-27Nb biomedical alloy. ${ }^{10,22}$ The study consisted in evaluating the structural analysis, the microstructure, the superficial hardness, the mechanical properties, the corrosion behavior in Carter-Brugirard artificial saliva and the biocompatibility by using human osteoblasts, fibroblastic cells and epithelial cells.

\section{Materials and Methods}

\subsection{Alloy preparation and gas nitriding process}

The Ti-27Nb alloy composition (27 at. \% of $\mathrm{Nb}$ and the balance at. \% of $\mathrm{Ti}$ ) was synthesized by the cold crucible levitation melting technique (CCLM) under high vacuum. Ingots were cold rolled up to a reduction level larger than $90 \%$ of the initial thickness whithout 
intermediate annealing. The final thickness of the cold rolled sheet was $1 \mathrm{~mm}$. From this sheet, tensile test samples and disc shape samples (diameter: $13 \mathrm{~mm}$, thickness: $1 \mathrm{~mm}$ ) were cut in order to carry out the different tests. Then, all samples were solution-treated in the $\beta$ phase domain at $850{ }^{\circ} \mathrm{C}$ for 30 min under high vacuum atmosphere in order to restore a fully recrystallized microstructure and finally water quenched to retain the metastable $\beta$ microstructure at room temperature.

The nitriding process consisted of a high temperature gas nitriding treatment, which was carried out at $950^{\circ} \mathrm{C}$ for $2 \mathrm{~h}$ under one controlled flow high-purity nitrogen atmosphere (N2 > 99.999\%). Before gas nitriding, all samples were mechanically polished in order to obtain smooth surfaces (“mirror polished”) or rough surfaces by using different SiC abrasive papers and colloidal silica suspension.

\subsection{Surface characterization methods}

Phase identification of the nitrided and non-nitrided surfaces was carried out by X-ray Diffraction (XRD) (CuK $\mathrm{Cu}_{\alpha 1}$ radiation). The microstructure was observed by optical microscopy (OM) and by scanning electron microscopy (SEM).

Superficial mechanical properties were studied by nano-indentation using a diamond Berkovich-type indenter. Load controlled indentation tests were carried out at room temperature and the tests were conducted using the Oliver and Pharr method. ${ }^{23}$ Nanoindentation measurements were performed with load values ranging from $5 \mathrm{mN}$ to $500 \mathrm{mN}$. During the entire loading and unloading cycle, the applied load and the displacement of the indenter were recorded continuously. Hardness values were extracted from the unloading curves according to the equivalent indenter method. For each load value, 10 nano-indentation profiles were done in order to obtain representative average values of the entire surface.

For the in-vitro biocompatibility tests, disc samples (diameter $13 \mathrm{~mm}$, thickness $1 \mathrm{~mm}$ ) were polished in order to obtain smooth or rough surfaces. For the rough surfaces, the samples were 
successively mechanically polished with different $\mathrm{SiC}$ abrasive papers from grade 80 to grade 220. For the "mirror polished" state (smooth surface), SiC abrasive papers (from grade 80 to grade 4000) were used followed by a final polishing with a colloidal silica suspension. The topography of the surface samples was observed by atomic force microscopy (AFM) in order to evaluate the different roughnesses. Tapping mode was used in an air atmosphere with a silicon tip. To evaluate the roughness 10 values were obtained from 80 X $80 \mu \mathrm{m}$ AFM scans taken in different areas of each surface. From these 10 values, an average roughness value, Ra, was then obtained ( \pm standard deviation) for each surface.

\subsection{Tensile tests}

The tensile test samples possess a normalized shape: $3 \mathrm{~mm}$ width, $1 \mathrm{~mm}$ in thickness and a gauge length of $15 \mathrm{~mm}$. The tensile tests were carried out until rupture with a tensile machine. Strain was measured with an extensometer and the strain rate used was $10^{-4} \mathrm{~s}^{-1}$.

\subsection{Corrosion resistance}

The corrosion resistance of the Ti-27Nb alloy before and after gas nitriding was tested in a Carter-Brugirard artificial saliva for different $\mathrm{pH}$ values. For comparison, corrosion behaviour of the commercially pure Cp-Ti (Grade 2) was also conducted in the frame of the present study as a reference. The corrosion resistance was evaluated from linear potentiodynamic polarization, applied for $\pm 50 \mathrm{mV}$ around the open circuit potential with a scan rate of 0.1 mV/s. The equipment used was a Voltalab 80 Potentiostat, PGZ 402, by Radiometer Analytical (Lyon, France). The VoltaMaster 4 (ver 7.9) program was used to adjust Tafel curves and directly supplied: corrosion current density, $\mathrm{i}_{\text {corr }}$; corrosion rate, $\mathrm{V}_{\text {corr }}$; polarization resistance, $R_{p}$. It also calculated the ion release rate $e^{8,24}$ that represents the total quantity of ions released into surrounding saliva and the porosity factor, $\mathrm{P}$ that was calculated using Tato and Landolt ${ }^{25}$ formula:

$$
P(\%)=\frac{R_{b}}{R_{n}} \times 100
$$


( $R_{b}$ and $R_{n}$ represent the resistance of the non-nitrided and nitrided alloy).

The protection efficiency, $\mathrm{E}$ of the nitrided layer was calculated ${ }^{26}$ using the corrosion current density for the non-nitrided, $\mathrm{i}_{\text {corr,b }}$ and the nitrided, $\mathrm{i}_{\text {corr,n }}$ alloy:

$E(\%)=\frac{i_{c o r r, b}-i_{c o r r, n}}{i_{c o r r, b}} \times 100$

The samples, (discs with diameter of $10 \mathrm{~mm}$ and $1 \mathrm{~mm}$ thickness) were cleaned by immersion for $30 \mathrm{~min}$ in acetone and $30 \mathrm{~min}$ in distilled water using an ultrasonic cleaner (Geoson LD050). Three samples were used for every experiment.

The oral environment contains corrosive substances such as citric acid, lactic acid, hydrochloric and hydrofluoric acids, hydrogen peroxide, fluorides, etc. ${ }^{27}$ which corrode the dental materials; the resulted compounds can affect the tooth esthetics and can cause inflammations, mutagenic and/or carcinogenic reactions.

The oral environment was reproduced by using a Carter-Brugirard artificial saliva of different pH values: $3.21 ; 7.48 ; 9.11 ; 0.05 \mathrm{M} \mathrm{NaF}$ doped saliva, $(\mathrm{pH}=8.21)$ which simulate the functional conditions from the oral cavity. ${ }^{28}$ The saliva composition was $(\mathrm{g} / \mathrm{L})$ : $\mathrm{NaCl}-0.7$; $\mathrm{KH}_{2} \mathrm{PO}_{4}-0.26 ; \mathrm{KSCN}-0.33 ; \mathrm{Na}_{2} \mathrm{HPO}_{4}-0.19 ; \mathrm{NaHCO}_{3}-1.5$; urea -0.13 .

\subsection{Cell viability assay}

The $\mathrm{SaOS}_{2}$ cell line (human osteosarcoma cell line- ATCC® ${ }^{\circledR} \mathrm{HTB}-85^{\mathrm{TM}}$ ), the KB cell line (human epithelial cell line, ATCC® CCL-17'TM) and the L929 cell line (mouse fibroblastic cell line, ATCC ${ }^{\circledR}$ CCL-1 ${ }^{\mathrm{TM}}$ ) were used in this study. Cells were cultured with basic culture medium composed of DMEM medium, supplemented with $10 \%$ foetal calf serum, $15 \mathrm{mM}$ HEPES buffer, 2 mM L-Glutamine, 100 UI.mL-1 penicillin and $100 \mu \mathrm{g} . \mathrm{mL}-1$ streptomycin at $37^{\circ} \mathrm{C}$ in a humidified incubator containing $5 \% \mathrm{CO}_{2}$. After reaching approximately $80 \%$ confluency, cells were harvested and subcultured. Twelve disc samples of each type (nitrided and non-nitrided Ti-27Nb, "smooth" or "rough" surfaces) were sterilized in an autoclave at 
$121{ }^{\circ} \mathrm{C}$ for $20 \mathrm{~min}$ and sealed individually with agarose into the wells of the 24-well culture plates. Surfaces were seeded with cells in $1 \mathrm{~mL}$ of basic culture medium at initial concentration of $4 \times 10^{4}, 1.4 \times 10^{4}$ and $1 \times 10^{4}$ cells.mL ${ }^{-1}$ for the three days assays with SaOS2, KB and L929 cell line respectively and of $1 \times 10^{4}, 2 \times 10^{3}, 1.2 \times 10^{3}$ cells.mL ${ }^{-1}$ for the 6 days assays. The medium was changed every third day up to 6 days.

After 3 and 6 days, seeded surfaces were incubated with a $1 \mathrm{mg} \cdot \mathrm{mL}-1$ MTT [3-(4,5-dimethyl thiazol-2-yl) 2,5-diphenyltetrazolium bromide] solution according to tetrazolium-based colorimetric assay described by Mosmann. $^{29}$ The mitochondrial enzyme succinatedehydrogenase within viable cells is able to reduce the yellow dye MTT to a purple coloured product (formazan crystals) which is soluble in dimethyl sulfoxide (DMSO). After ten minutes agitation, the optical densities (OD) of the solutions were read at $550 \mathrm{~nm}$ with a spectrophotometer (Sunrise Tecan). The OD was proportional to the number of viable, metabolically active cells present. The assay was performed on D3 and D6. All the experiments were conducted in triplicate.

Statistical analysis method: Data were analysed by one-way analysis of variance (ANOVA) followed by Fisher's Protected Least Significant Difference (PLSD) with values of $p<0.05$ considered statistically significant using StatView v5.0 software.

\section{Results}

\subsection{Surface analysis}

XRD patterns from both nitrided and non-nitrided Ti-27Nb alloy are presented in Fig. 1. For the non-nitrided surface, the diffracted peaks are all related to the $\beta$ phase (body centred cubic) which constitutes the microstructure of the bulk alloy. After gas nitriding, additional peaks can be observed and are attributed to the presence of $\mathrm{TiN}, \mathrm{Ti}_{2} \mathrm{~N}$ and $\alpha$-Ti formation in surface. 
Macrographies of the nitrided and non-nitrided Ti-27Nb samples are presented in Fig. 2a. A clear difference of the superficial aspect can be observed. The non-nitrided Ti-27Nb alloy presents a classical metallic grey colour while the nitrided one presents a golden yellow colour. This golden yellow colour is typical of the presence of a nitride coating in surface. A typical optical micrograph of the microstructure observed in cross section near the surface of the nitrided Ti-27Nb alloy is presented in Fig. 2b. This micrograph shows that the nitrided sample presents an equiaxed $\beta$-grain microstructure in the core with a grain size of a few ten micrometres and a modified region in surface (around $15 \mu \mathrm{m}$ in thickness) consisting in a very thin $\mathrm{TiN} / \mathrm{Ti}_{2} \mathrm{~N}$ layer at the extreme surface followed by a larger $\mathrm{N}$-enriched zone containing parallel needles of $\alpha$-titanium. The SEM image of the cross-section displayed in Fig. 2c reveals the very thin uniform nitrided layer (external zone, $0.5 \mu \mathrm{m}$ in thickness) with sharp interface with the bulk alloy. Under the nitrided layer, the nitrogen diffusion layer is clearly visible and contains parallel needles $(0.5-1 \mu \mathrm{m}$ thickness) of $\alpha$-titanium enriched with nitrogen.

From the AFM maps, uniform roughnesses were observed from both nitrided and non-nitrided samples. For the smooth samples, the roughness value (Ra) was measured to be $12 \pm 2 \mathrm{~nm}$ for the non-nitrided Ti-27Nb alloy and $55 \pm 4 \mathrm{~nm}$ for the nitrided Ti-27Nb alloy, respectively. For the rough surfaced samples, Ra was measured to be $422 \pm 81 \mathrm{~nm}$ for the non-nitrided Ti-27Nb alloy and $452 \pm 25 \mathrm{~nm}$ for the nitrided Ti-27Nb alloy, respectively.

\subsection{Superficial hardness}

Mean hardness versus tip penetration depth profiles of nitrided and non-nitrided Ti-27Nb obtained by nanoindentation are shown in Fig. 3. For the nitrided samples, the nanoindentation profile begins on the surface at high hardness values. Then the hardness values of nitrided samples decrease gradually until reaching the same hardness values of the non-nitrided sample in the core of the sample. The non-nitrided sample nanoindentation 
profile shows a gradual decrease in the hardness from the surface to the core. Maximum hardness values are about $400 \mathrm{HV}$ for non-treated Ti-27Nb and $2000 \mathrm{HV}$ for nitrided samples which correspond to an increase of 4 to 5-fold of the hardness of core.

\subsection{Tensile test results}

An investigation of the tensile properties of the nitrided and non-nitrided Ti-27Nb alloy was carried out and compared to tensile properties of commercially pure titanium (Cp-Ti, purity: 99.6\%). In Fig. 4a, a non-linear elastic behaviour can be clearly observed for the nitrided and non-nitrided $\mathrm{Ti}-27 \mathrm{Nb}$ alloy by comparison to $\mathrm{Cp}-\mathrm{Ti}$. The tensile curves of nitrided and nonnitrided samples exhibit a double yielding behaviour. This is a typical characteristic of the superelastic property due to stress-induced $\alpha$ "' martensitic transformation, which is known to occur in this alloy composition. ${ }^{22}$

The Young's modulus values which were measured at the origin of the tensile curve (incipient modulus defined by the slope of the tangent at zero stress) are 55 GPa for nitrided and nonnitrided Ti-27Nb alloy (Fig. 4b). For Cp-Ti, the tensile curve shows classical linear elastic behaviour with a constant Young's modulus evaluated between 102-104 GPa whereas the nitrided and non-nitrided Ti-27Nb alloy exhibits a non-linear elastic domain. Consequently, a clear lower Young's modulus closer to the bone one is obtained for the nitrided Ti-2Nb alloy compared to Cp-Ti (two times lower).

\subsection{Corrosion resistance results}

The corrosion parameters evaluated in this study were obtained from Tafel representations (examples at $\mathrm{pH}=7.48$ are presented in Fig. 5) and are listed in Table 1. The values provided are the mean values for the 3 samples used. From this table, one can observe that the corrosion current densities, corrosion and ion release rates for the non-nitrided Ti-27Nb alloy are decreased by about $4.4-6.2$ times compared to Cp-Ti. On the other hand, the polarization resistance of the non-nitrided $\mathrm{Ti}-27 \mathrm{Nb}$ alloy is increased compared to the $\mathrm{Cp}-\mathrm{Ti}$ alloy, proving 
a more resistant passive film on this alloy surface. ${ }^{30}$ For the nitrided Ti-27Nb alloy, all corrosion parameters were further improved: the corrosion current densities, corrosion and ion release rates are decreased by about $14-21$ times compared to the non-nitrided Ti-27Nb alloy. Similarly, the polarization resistance is increased by about $3-4$ times for the nitrided Ti-27Nb alloy compared to the non-nitrided one. Additionally, the protective efficiency factor, E, has very high values, over 93\%, reflecting very good protective action of the applied nitrided coating. The nitrided Ti-27Nb alloy efficiency (E) is increased and its porosity (P) decreased compared to Cp-Ti. Thus, all corrosion parameters for the nitrided Ti-27Nb alloy indicated a better corrosion resistance compared to $\mathrm{Cp}-\mathrm{Ti}$ and non-nitrided Ti-27Nb alloy for all $\mathrm{pH}$ values.

\subsection{Biocompatibility results}

The cell viability and proliferation were evaluated by the MTT assay. Figure 6 shows the ratios (\%) of cell viability measured from cells seeded on nitrided and non-nitrided Ti-27Nb alloy, compared to the cell viability measured from cells seeded on TCPs after three days (D3) and six days (D6) of contact. "Smooth" surfaces $(\mathrm{Ra} \approx 0.05 \mu \mathrm{m})$ and "rough" surfaces $(\mathrm{Ra} \approx 0.4 \mu \mathrm{m})$ were both tested. For $\mathrm{SaOS}_{2}$ cell cultures (Fig. 6a) at $\mathrm{D} 3$, there is no significant difference in cell viability for nitrided and non-nitrided surfaces regardless of roughness. At D6 there is no significant difference for the smooth surfaces while for the rough surfaces the cell viability is statistically higher on the nitrided samples (62\%) compared to the non-nitrided samples (55\%) $(\mathrm{p}<0.05)$. For KB cell cultures (Fig. 6b) the cell viability is statistically higher on the rough nitrided samples $(\mathrm{p}<0.05)$ compared to the rough non-nitrided samples at D3 (58\% and 51\% respectively) and at D6 (83\% and 76\% respectively). For the smooth surfaces there is no significant difference at D3 while at D6 the cell viability is statistically lower on the nitrided samples $(66 \%)$ compared to the non-nitrided samples $(75 \%)(\mathrm{p}<0.05)$. For L929 cell cultures (Fig. 6c) at D3, there is no significant difference in cell viability for 
nitrided and non-nitrided surfaces regardless of roughness. At D6 there is no significant difference for the rough surfaces while for the smooth surfaces the cell viability is statistically lower on the nitrided samples (57\%) compared to the non-nitrided samples (62\%) (p < 0.05).

\section{Discussion}

Numerous methods are used to create nitrided coatings in various dental materials: Physical Vapor Deposition, Chemical Vapor Deposition and thermal nitriding. In this study the samples were nitrided by gas nitriding, a simple method used for engineering applications. ${ }^{31}$ Gas nitriding has the main advantage to be used independently of the shape of the piece and does not require special equipment. With this method, both $\mathrm{TiN}$ and $\mathrm{Ti}_{2} \mathrm{~N}$ nitrides were identified on the surface sample (thickness of about $0.5 \mu \mathrm{m}$ ). The coating is not only composed of a compact layer of $\mathrm{TiN} / \mathrm{Ti}_{2} \mathrm{~N}$ but also of internal layered structures (parallel needles of $\alpha$-titanium enriched with nitrogen, $15 \mu$ m thickness) due to the nitrogen diffusion. The presence of this coating structures $\left(\mathrm{TiN}, \mathrm{Ti}_{2} \mathrm{~N}, \alpha\right.$-titanium enriched with nitrogen) causes a 4 times increase of the superficial hardness at the extreme surface. According to the nanoindentation profile obtained, the hardening effect is mainly due to the presence of TiN and $\mathrm{Ti}_{2} \mathrm{~N}$ nitrides on the surface. As shown with the tensile tests, the low modulus of $\mathrm{Ti}-27 \mathrm{Nb}$ alloy is not affected by the gas nitriding treatment. Hence, the nitrided Ti-27Nb alloy presents both low elastic modulus and high superficial hardness that make it suitable for dental implant applications. As other key important mechanical properties are required for long term functional loading, fatigue strength evaluation and cyclic abrasion test under simulated use conditions will be the subject of a future investigation.

The decrease of the corrosion current densities, $\mathrm{i}_{\text {corr }}$, corrosion rates, $\mathrm{V}_{\text {corr }}$, and ion release rates of the non-nitrided $\mathrm{Ti}-27 \mathrm{Nb}$ alloy in comparison with $\mathrm{Cp}-\mathrm{Ti}$ (of about $4.4-6.2$ times) is due to the better corrosion resistance of the native passive film on Ti-27Nb alloy surface. 
Also, the increase of the polarization resistance, $\mathrm{R}_{\mathrm{p}}$, for the non-nitrided Ti-27Nb alloy proves that the native passive film existing on this alloy surface is more resistant than those on Cp$\mathrm{Ti}^{30}$ Improvement of the values of $\mathrm{i}_{\text {corr }}, \mathrm{V}_{\text {corr }}$, ion release rate, and $\mathrm{R}_{\mathrm{p}}$ for the nitrided Ti-27Nb alloy prove that the nitride layer formed in surface acts as a very protective barrier and confers a high chemical stability to the substrate. ${ }^{26,32-35}$ For biocompatibility tests, three cell culture lines were used in this study: bone cells $\left(\mathrm{SaOS}_{2}\right)$, oral epithelial cells (KB) and fibroblastic cells (L929) in order to be close to clinical conditions. Cell growth and metabolic activity of cells were investigated on nitrided and non-nitrided Ti-27Nb alloy for comparison. The objective was to prove the lack of cytotoxicity and cell growth supporting properties of the nitrided Ti-27Nb alloy.

At D3 regardless the cell lines there is no significant difference between the nitrided and nonnitrided samples except for $\mathrm{KB}$ cells seeded on the rough nitrided samples. Even if the viability is higher on this surface (58\% VS 51\%), this difference does not lead to a real positive biological effect. These results are in concordance with studies applying bone marrow human mesenchymal stem cells and bone marrow human stromal cells. ${ }^{36,37}$ At D6 regardless the cell lines, the cell viability is systematically lower on the smooth nitrided samples compared to the smooth non-nitrided samples. On the contrary, the cell viability of $\mathrm{SaOS}_{2}$ is statistically higher $(\mathrm{p} \leq 0.05)$ on the rough nitrided samples compared to the rough non-nitrided samples. Hence, the variation of the chemical composition leads to a biological effect, but this effect is reversed depending on the roughness. It was previously shown that nitrided surfaces and rough surfaces are slightly more hydrophilic. ${ }^{38}$ This study shows that the rough nitrided surfaces can stimulate cell growth in vitro compared to the corresponding nontreated samples. These results are in agreement with previous works ${ }^{19,39,40}$ showing that cell viability and proliferation increased on TiN and TiAlN films as compared to uncoated alloy surfaces. 
The differences of relative cell viability between nitrided and non-nitrided samples are less than $10 \%$. By determining the percentage of S-phase cells, we found out comparable values on the different analysed surfaces (data not shown). No significant changes in the cycle phases were found for all the substrates. This finding suggests that the nitrided Ti-27Nb alloy does not inhibit the cells from entering the S-phase, even at 6 days post-seeding when the cells formed about 100\% confluent monolayer. Hence, cells proliferate on the nitrided and non-nitrided surface to almost the same extent without any positive or negative effect of the chemical composition.

\section{Conclusion}

In this work, a high temperature gas nitriding treatment was used for the first time to modify surface properties of $\mathrm{Ti}-27 \mathrm{Nb}$ alloy. The formation of a $\mathrm{TiN} / \mathrm{Ti}_{2} \mathrm{~N}$ layer was observed and a hardness increase was detected in the first $800 \mathrm{~nm}$. A low elastic modulus close to that of bone was obtained for both nitrided and non-nitrided Ti-27Nb alloy. This is of significant importance to establish a gradual mechanical transition with the surrounding bone. All corrosion parameters for the nitrided Ti-27Nb alloy indicated a better corrosion resistance compared to $\mathrm{Cp}-\mathrm{Ti}$ and non-nitrided $\mathrm{Ti}-27 \mathrm{Nb}$ alloy, whatever the $\mathrm{pH}$ of the solution. Improvement of the values of $\mathrm{i}_{\text {corr }}, \mathrm{V}_{\text {corr }}$, ion release rate, and $\mathrm{R}_{\mathrm{p}}$ for the nitrided Ti-27Nb alloy prove that the nitride layer formed in surface acts as a very protective barrier and confers a high chemical stability to the substrate. In vitro tests performed on human osteoblasts, fibroblastic cells and epithelial cells indicated that both non-nitrided and nitrided Ti-27Nb alloy exhibited a good level of cytocompatibility. The cell viability was enhanced on the rough nitrided Ti-27Nb alloy. A higher life expectancy of dental implants made of non-toxic elements is of particular importance since dental implants are now expected to serve for much 
longer periods. Hence the nitrided Ti-27Nb alloy is a good candidate for dental implant applications thanks to the observed mechanical properties and the biocompatibility.

\section{References}

1. Branemark R, Branemark PI, Rydevik B, Myers RR. Osseointegration in skeletal reconstruction and rehabilitation: a review. J Rehabil Res Dev 2001;38(2):175-81.

2. Abdel-Hady Gepreel M, Niinomi M. Biocompatibility of Ti-alloys for long-term implantation. J Mech Behav Biomed Mater 2013;20:407-15.

3. Niinomi M. Mechanical biocompatibilities of titanium alloys for biomedical applications. J Mech Behav Biomed Mater 2008;1(1):30-42.

4. Huiskes R, Weinans H, Van Rietbergen B. The Relationship Between Stress Shielding and Bone Resorption Around Total Hip Stems and the Effects of Flexible Materials. Clinical Orthopaedics and Related Research 1992;274:124-134.

5. Geetha M, Singh AK, Asokamani R, Gogia AK. Ti based biomaterials, the ultimate choice for orthopaedic implants - A review. Progress in Materials Science 2009;54(3):397-425.

6. Jirka I, Vandrovcova M, Frank O, Tolde Z, Plsek J, Luxbacher T, Bacakova L, Stary $\mathrm{V}$. On the role of Nb-related sites of an oxidized beta-TiNb alloy surface in its interaction with osteoblast-like MG-63 cells. Mater Sci Eng C Mater Biol Appl 2013;33(3):1636-45.

7. Miyazaki S, Kim HY, Hosoda H. Development and characterization of Ni-free Ti-base shape memory and superelastic alloys. Materials Science and Engineering: A 2006;438-440:18-24. 
8. Gordin DM, Ion R, Vasilescu C, Drob SI, Cimpean A, Gloriant T. Potentiality of the "Gum Metal" titanium-based alloy for biomedical applications. Mater Sci Eng C Mater Biol Appl 2014;44:362-70.

9. Liu X, Chu P, Ding C. Surface modification of titanium, titanium alloys, and related materials for biomedical applications. Materials Science and Engineering: R: Reports 2004;47(3-4):49-121.

10. Prasad S, Ehrensberger M, Gibson MP, Kim H, Monaco EA. Biomaterial properties of titanium in dentistry. Journal of Oral Biosciences 2015;57(4):192-199.

11. Kim HY, Ikehara Y, Kim JI, Hosoda H, Miyazaki S. Martensitic transformation, shape memory effect and superelasticity of $\mathrm{Ti}-\mathrm{Nb}$ binary alloys. Acta Materialia 2006;54(9):2419-2429.

12. Lohmann CH, Schwartz Z, Koster G, Jahn U, Buchhorn GH, MacDougall MJ, Casasola D, Liu Y, Sylvia VL, Dean DD and others. Phagocytosis of wear debris by osteoblasts affects differentiation and local factor production in a manner dependent on particle composition. Biomaterials 2000;21(6):551-61.

13. Cremasco A, Osório WR, Freire CMA, Garcia A, Caram R. Electrochemical corrosion behavior of a Ti-35Nb alloy for medical prostheses. Electrochimica Acta 2008;53(14):4867-4874.

14. Vasilescu E, Drob P, Vasilescu C, Drob SI, Bertrand E, Gordin DM, Gloriant T. Corrosion resistance of the new Ti-25Ta-25Nb alloy in severe functional conditions. Materials and Corrosion 2010;61(11):947-954.

15. Wachi T, Shuto T, Shinohara Y, Matono Y, Makihira S. Release of titanium ions from an implant surface and their effect on cytokine production related to alveolar bone resorption. Toxicology 2015;327:1-9. 
16. Barranco V, Escudero ML, Garcia-Alonso MC. Influence of the microstructure and topography on the barrier properties of oxide scales generated on blasted Ti6Al4V surfaces. Acta Biomater 2011;7(6):2716-25.

17. Woldemedhin MT, Raabe D, Hassel AW. Characterization of thin anodic oxides of $\mathrm{Ti}-\mathrm{Nb}$ alloys by electrochemical impedance spectroscopy. Electrochimica Acta 2012;82:324-332.

18. Yoshinari M, Oda Y, Kato T, Okuda K. Influence of surface modifications to titanium on antibacterial activity in vitro. Biomaterials 2001;22(14):2043-8.

19. Chien CC, Liu KT, Duh JG, Chang KW, Chung KH. Effect of nitride film coatings on cell compatibility. Dent Mater 2008;24(7):986-93.

20. Huang X, Etsion I, Shao T. Effects of elastic modulus mismatch between coating and substrate on the friction and wear properties of TiN and TiAlN coating systems. Wear 2015;338-339:54-61.

21. Larsson Wexell C, Thomsen P, Aronsson BO, Tengvall P, Rodahl M, Lausmaa J, Kasemo B, Ericson LE. Bone response to surface-modified titanium implants: studies on the early tissue response to implants with different surface characteristics. Int $\mathrm{J}$ Biomater 2013;2013:412-482.

22. Ramarolahy A, Castany P, Prima F, Laheurte P, Peron I, Gloriant T. Microstructure and mechanical behavior of superelastic Ti-24Nb-0.5O and Ti-24Nb-0.5N biomedical alloys. J Mech Behav Biomed Mater 2012;9:83-90.

23. Oliver WC, Pharr GM. Measurement of hardness and elastic modulus by instrumented indentation: Advances in understanding and refinements to methodology. Journal of Materials Research 2011;19(01):3-20. 
24. Calderon Moreno JM, Vasilescu E, Drob P, Osiceanu P, Vasilescu C, Drob SI, Popa M. Surface and electrochemical characterization of a new ternary titanium based alloy behaviour in electrolytes of varying pH. Corrosion Science 2013;77:52-63.

25. Tato W. Electrochemical Determination of the Porosity of Single and Duplex PVD Coatings of Titanium and Titanium Nitride on Brass. Journal of The Electrochemical Society 1998;145(12):4173.

26. Kim W-G, Choe H-C. Effects of TiN coating on the corrosion of nanostructured Ti30Ta-XZr alloys for dental implants. Applied Surface Science 2012;258(6):19291934.

27. Souza JC, Barbosa SL, Ariza EA, Henriques M, Teughels W, Ponthiaux P, Celis JP, Rocha LA. How do titanium and Ti6Al4V corrode in fluoridated medium as found in the oral cavity? An in vitro study. Mater Sci Eng C Mater Biol Appl 2015;47:384-93.

28. Popa MV, Vasilescu E, Drob P, Vasilescu C, Demetrescu I, Ionita D. Long-term assessment of the implant titanium material--artificial saliva interface. J Mater Sci Mater Med 2008;19(1):1-9.

29. Mosmann T. Rapid colorimetric assay for cellular growth and survival: application to proliferation and cytotoxicity assays. J Immunol Methods 1983;65(1-2):55-63.

30. Assis SL, Costa I. Electrochemical evaluation of Ti-13Nb-13Zr, Ti-6Al-4V and Ti6Al-7Nb alloys for biomedical application by long-term immersion tests. Materials and Corrosion 2007;58(5):329-333.

31. Zhecheva A, Sha W, Malinov S, Long A. Enhancing the microstructure and properties of titanium alloys through nitriding and other surface engineering methods. Surface and Coatings Technology 2005;200(7):2192-2207.

32. Lin N, Huang X, Zhang X, Fan A, Qin L, Tang B. In vitro assessments on bacterial adhesion and corrosion performance of TiN coating on Ti6Al4V titanium alloy 
synthesized by multi-arc ion plating. Applied Surface Science 2012;258(18):70477051.

33. Savonov GS, Ueda M, Oliveira RM, Otani C. Electrochemical behavior of the Ti6Al4V alloy implanted by nitrogen PIII. Surface and Coatings Technology 2011;206(7):2017-2020.

34. Yildiz F, Yetim AF, Alsaran A, Çelik A. Plasma nitriding behavior of Ti6Al4V orthopedic alloy. Surface and Coatings Technology 2008;202(11):2471-2476.

35. Zhao X, Yan D, Li S, Lu C. The effect of heat treatment on the electrochemical corrosion behavior of reactive plasma-sprayed TiN coatings. Applied Surface Science 2011;257(23):10078-10083.

36. Annunziata M, Guida L, Perillo L, Aversa R, Passaro I, Oliva A. Biological response of human bone marrow stromal cells to sandblasted titanium nitride-coated implant surfaces. J Mater Sci Mater Med 2008;19(12):3585-91.

37. Annunziata M, Oliva A, Basile MA, Giordano M, Mazzola N, Rizzo A, Lanza A, Guida L. The effects of titanium nitride-coating on the topographic and biological features of TPS implant surfaces. J Dent 2011;39(11):720-8.

38. Alves C, Guerra Neto CLB, Morais GHS, da Silva CF, Hajek V. Nitriding of titanium disks and industrial dental implants using hollow cathode discharge. Surface and Coatings Technology 2006;200(11):3657-3663.

39. Gordin DM, Gloriant T, Chane-Pane V, Busardo D, Mitran V, Hoche D, Vasilescu C, Drob SI, Cimpean A. Surface characterization and biocompatibility of titanium alloys implanted with nitrogen by Hardion+ technology. J Mater Sci Mater Med 2012;23(12):2953-66. 
40. Groessner-Schreiber B, Neubert A, Muller WD, Hopp M, Griepentrog M, Lange KP. Fibroblast growth on surface-modified dental implants: an in vitro study. J Biomed Mater Res A 2003;64(4):591-9.

\section{Figure legends}

Fig. 1 XRD patterns of nitrided and non-nitrided Ti-27Nb alloy

Fig. 2 a Photography of the samples: Ti-27Nb (grey colour) and nitrided Ti-27Nb (golden yellow colour). b Optical micrograph (polarized light) showing the cross-section microstructure. c SEM image showing the cross-section microstructure in surface of the nitrided Ti-27Nb alloy. The very thin uniform nitrided layer $(0.5 \mu \mathrm{m}$ in thickness) is visible at the external zone

Fig. 3 Hardness profiles of nitrided and non-nitrided Ti-27Nb alloy

Fig. 4 a Stress strain tensile curves of Cp-Ti, nitrided and non-nitrided Ti-27Nb alloy. $\mathbf{b}$ The Young's modulus measured at the origin of the tensile curves

Fig. 5 Tafel representations for the non-nitrided and nitrided Ti-27Nb alloy in CarterBrugirard saliva at saliva $\mathrm{pH}=7.48$

Fig. 6 MTT cell proliferation assays from cell lines cultured on nitrided and non-nitrided Ti27Nb alloy. a SaOS 2 cell line. b KB cell line. c L929 cell line. "Smooth" surfaces $(\mathrm{Ra} \approx 0.05$ $\mu \mathrm{m})$ and "rough" surfaces $(\mathrm{Ra} \approx 0.4 \mu \mathrm{m})$ were both tested. Results are presented as relative proliferation rate compared to control (TCPs). ${ }^{*} \mathrm{p}<0.05$ for cells in contact with non-nitrided $\mathrm{Ti} 27 \mathrm{Nb}$ versus cells on the corresponding nitrided samples 


\begin{tabular}{|c|c|c|c|c|c|c|c|}
\hline Material & $\begin{array}{l}\mathrm{i}_{\text {corr }} \\
\left(\mu \mathrm{A} / \mathrm{cm}^{2}\right)\end{array}$ & $\begin{array}{l}E \\
(\%)\end{array}$ & $\begin{array}{l}V_{\text {corr }} \\
(\mu \mathrm{m} / \mathrm{Y})\end{array}$ & $\begin{array}{l}\text { Ion release } \\
\left(\mathrm{ng} / \mathrm{cm}^{2}\right)\end{array}$ & $\begin{array}{l}\mathrm{R}_{\mathrm{p}} \\
\left(\mathrm{k} \Omega \cdot \mathrm{cm}^{2}\right)\end{array}$ & $\begin{array}{l}P \\
(\%)\end{array}$ & Resistance class \\
\hline \multicolumn{8}{|c|}{ Saliva Carter-Brugirard pH = 3.21} \\
\hline $\mathrm{Cp}-\mathrm{Ti}$ & 0.198 & - & 1.83 & 185.93 & 665.2 & - & Very Stable \\
\hline $\mathrm{Ti}-27 \mathrm{Nb}$ & 0.041 & - & 0.379 & 38.59 & 701.3 & - & Perfectly Stable \\
\hline Nitrided Ti27Nb & 0.0023 & 94.4 & 0.021 & 2.13 & 2928.9 & 31.46 & Perfectly Stable \\
\hline \multicolumn{8}{|c|}{ Saliva Carter-Brugirard pH = 7.48} \\
\hline $\mathrm{Cp}-\mathrm{Ti}$ & 0.174 & - & 1.61 & 163.58 & 779.6 & - & Very Stable \\
\hline $\mathrm{Ti}-27 \mathrm{Nb}$ & 0.028 & - & 0.259 & 26.31 & 987.3 & - & Perfectly Stable \\
\hline Nitrided Ti27Nb & 0.0015 & 94.6 & 0.0139 & 1.41 & 3114.6 & 31.70 & Perfectly Stable \\
\hline \multicolumn{8}{|c|}{ Saliva Carter-Brugirard pH = 9.11} \\
\hline $\mathrm{Cp}-\mathrm{Ti}$ & 0.185 & - & 1.71 & 173.74 & 690.1 & - & Very Stable \\
\hline $\mathrm{Ti}-27 \mathrm{Nb}$ & 0.042 & - & 0.388 & 39.42 & 994.8 & - & Perfectly Stable \\
\hline Nitrided Ti27Nb & 0.0029 & 93.1 & 0.027 & 2.72 & 2968.5 & 33.51 & Perfectly Stable \\
\hline \multicolumn{8}{|c|}{ Saliva Carter-Brugirard + 0.05M NaF, pH = 8.21 } \\
\hline $\mathrm{Cp}-\mathrm{Ti}$ & 0.283 & - & 2.446 & 192.25 & 391.4 & - & Very Stable \\
\hline $\mathrm{Ti}-27 \mathrm{Nb}$ & 0.051 & - & 0.472 & 47.70 & 715.3 & - & Perfectly Stable \\
\hline Nitrided Ti27Nb & 0.0054 & 93.3 & 0.048 & 4.88 & 2178.9 & 32.82 & Perfectly Stable \\
\hline
\end{tabular}

Table 1 Main corrosion parameters for Cp-Ti, nitrided and non-nitrided Ti-27Nb alloys in Carter-Brugirard saliva of different $\mathrm{pH}$ values. 


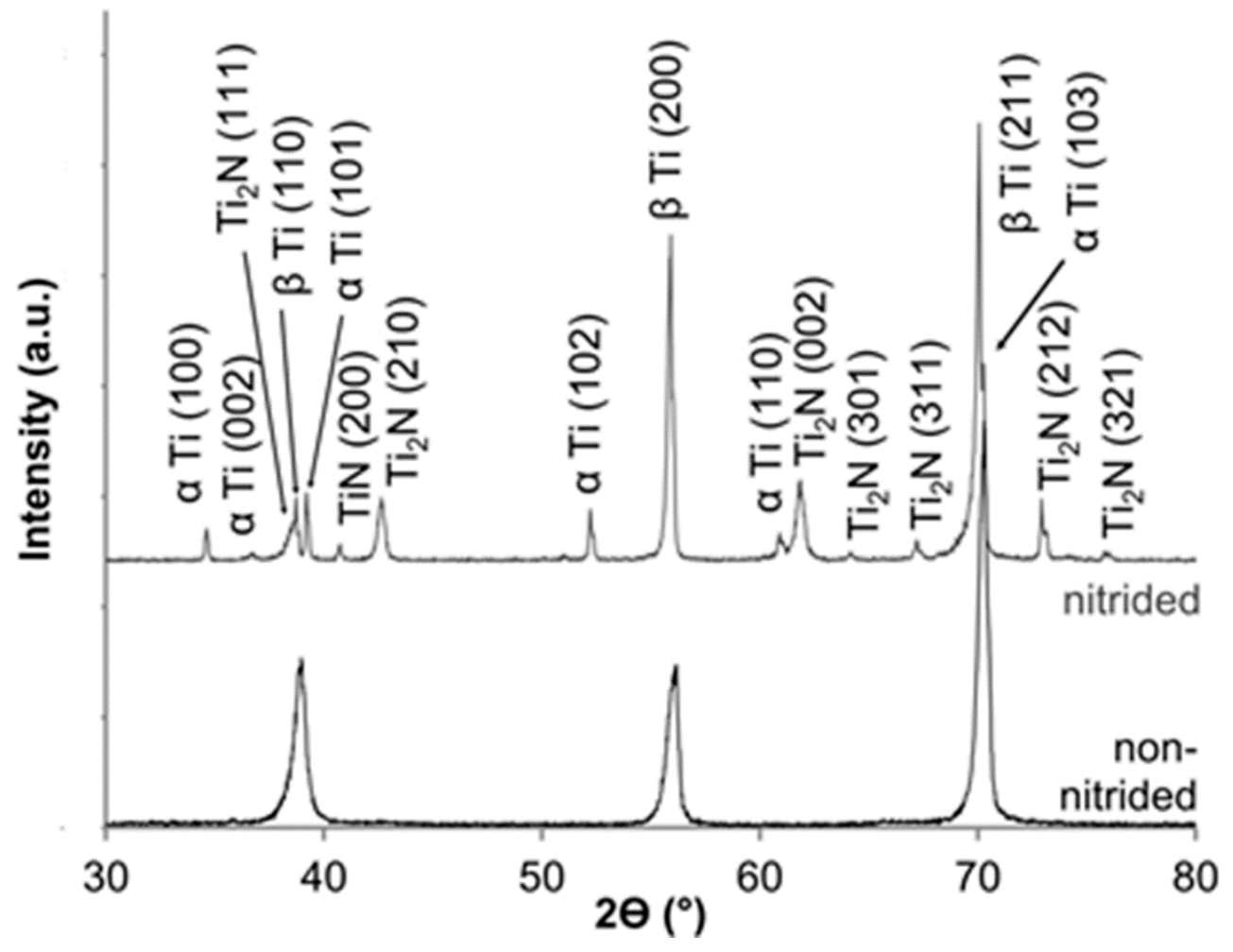

Fig. 1 XRD patterns of nitrided and non-nitrided Ti-27Nb alloy 

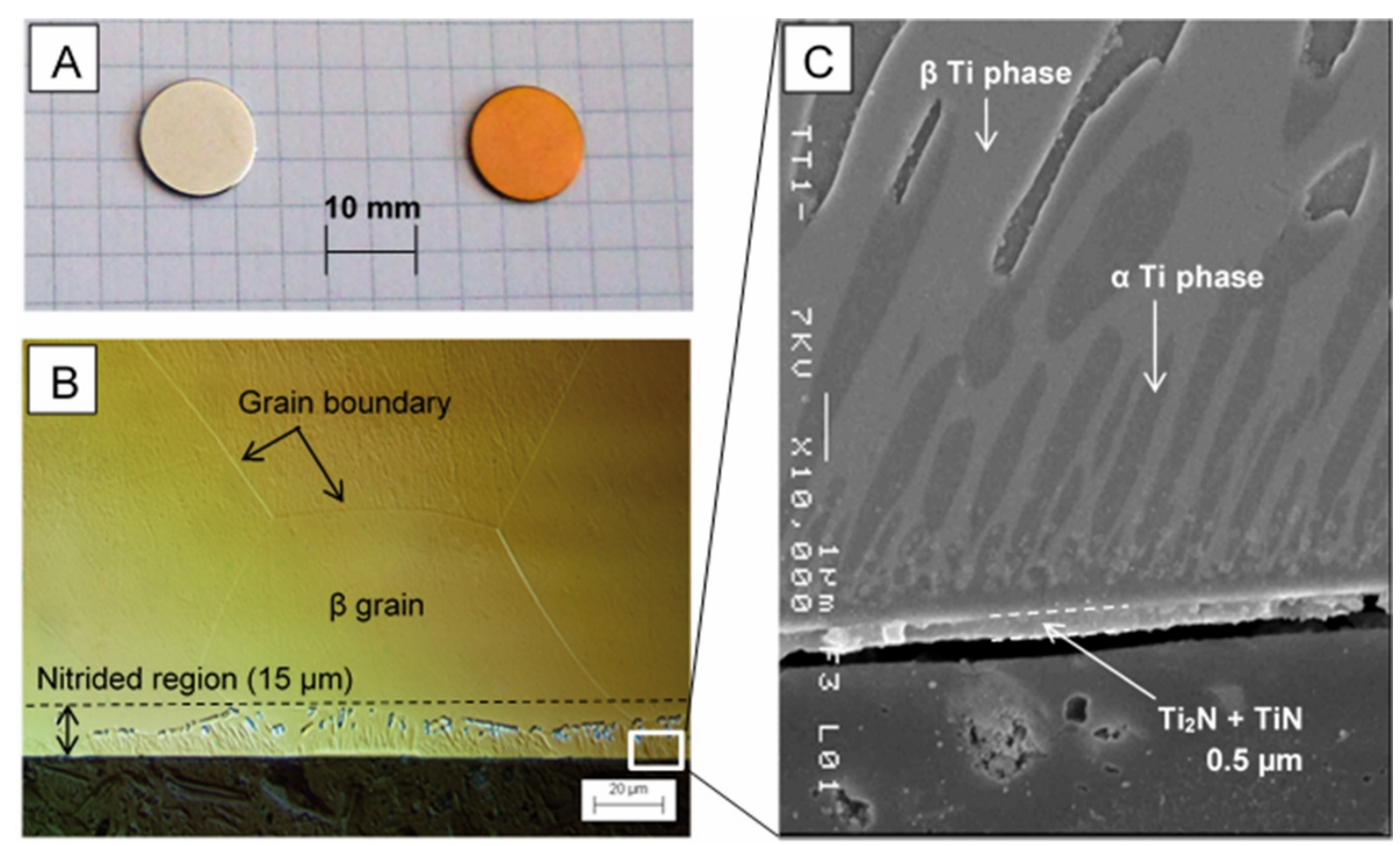

Fig. 2 a Photography of the samples: Ti-27Nb (grey colour) and nitrided Ti-27Nb (golden yellow colour). b Optical micrograph (polarized light) showing the cross-section microstructure. c SEM image showing the cross-section microstructure in surface of the nitrided Ti-27Nb alloy. The very thin uniform nitrided layer $(0.5 \mu \mathrm{m}$ in thickness) is visible at the external zone 


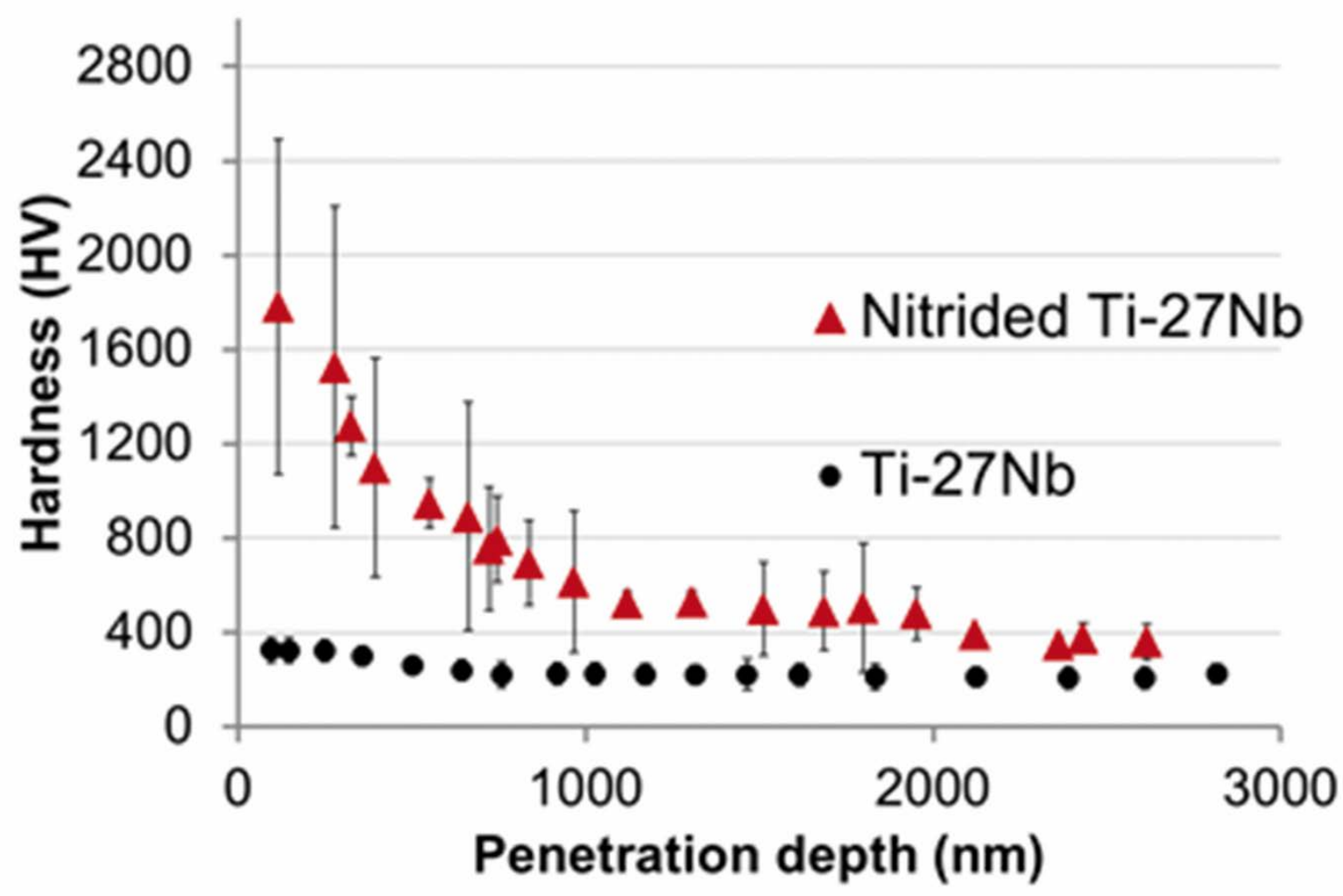

Fig. 3 Hardness profiles of nitrided and non-nitrided Ti-27Nb alloy 
A

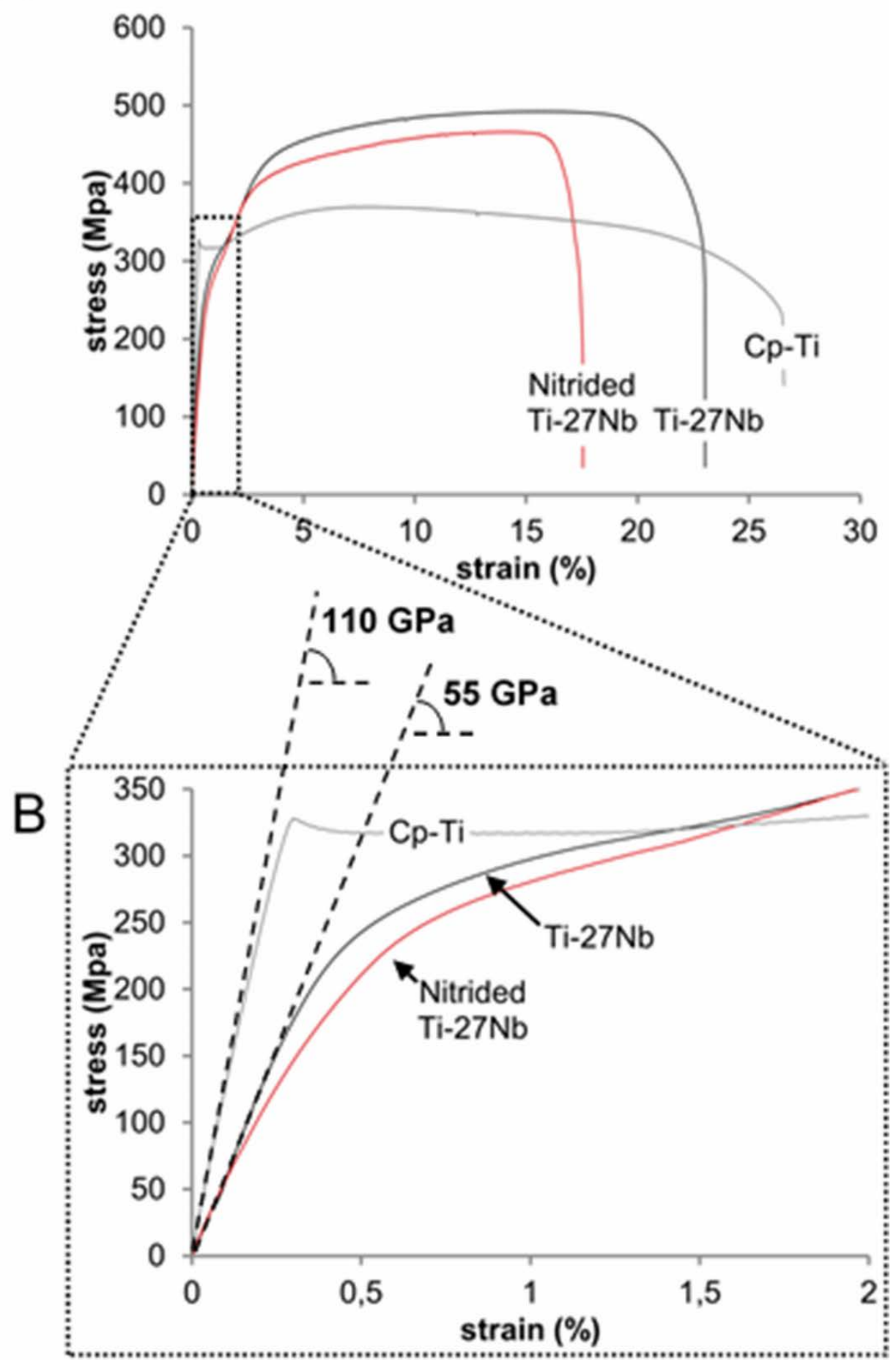

Fig. 4 a Stress strain tensile curves of Cp-Ti, nitrided and non-nitrided Ti-27Nb alloy. b The Young's modulus measured at the origin of the tensile curves 

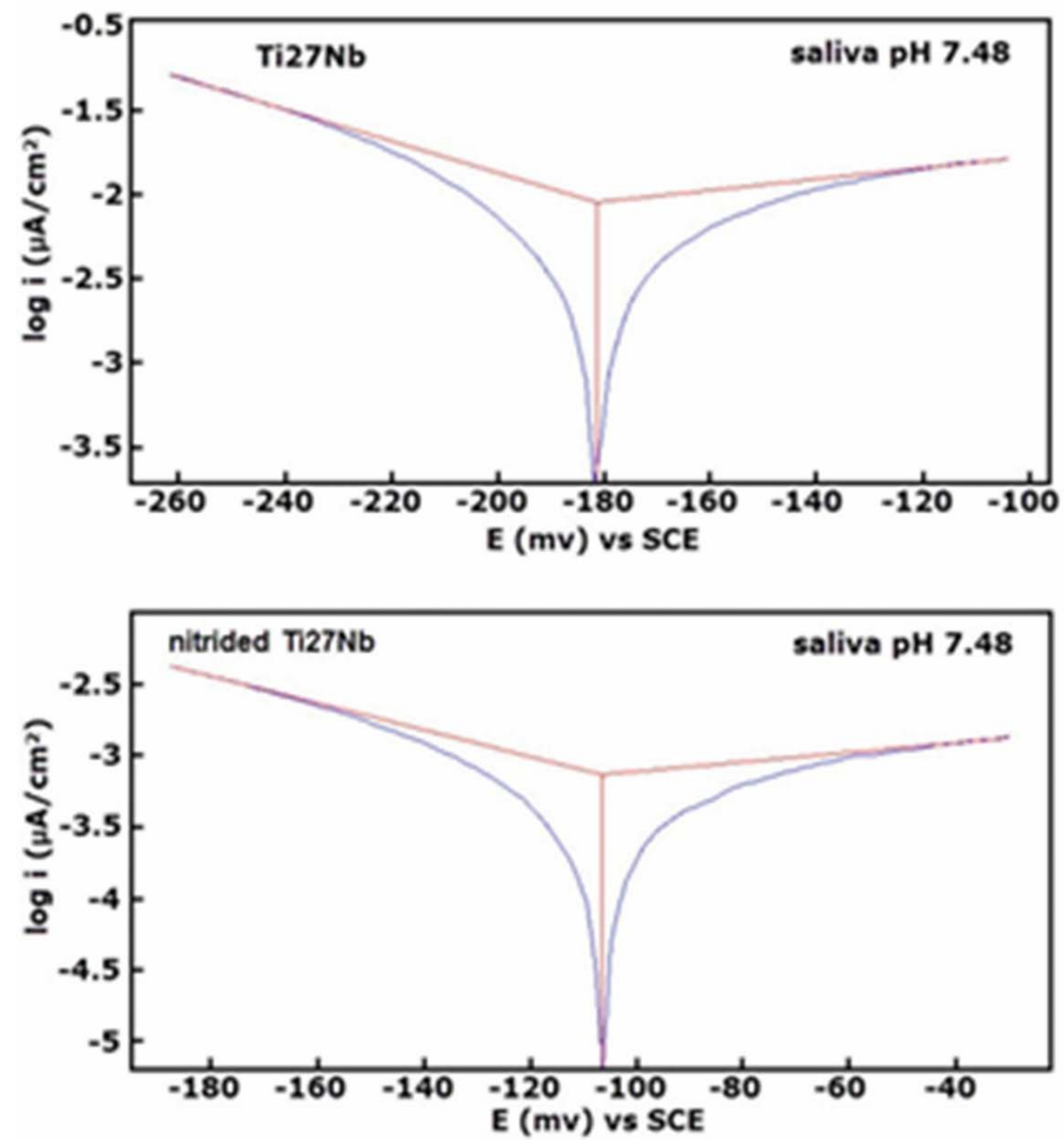

Fig. 5 Tafel representations for the non-nitrided and nitrided Ti-27Nb alloy in CarterBrugirard saliva at saliva $\mathrm{pH}=7.48$ 

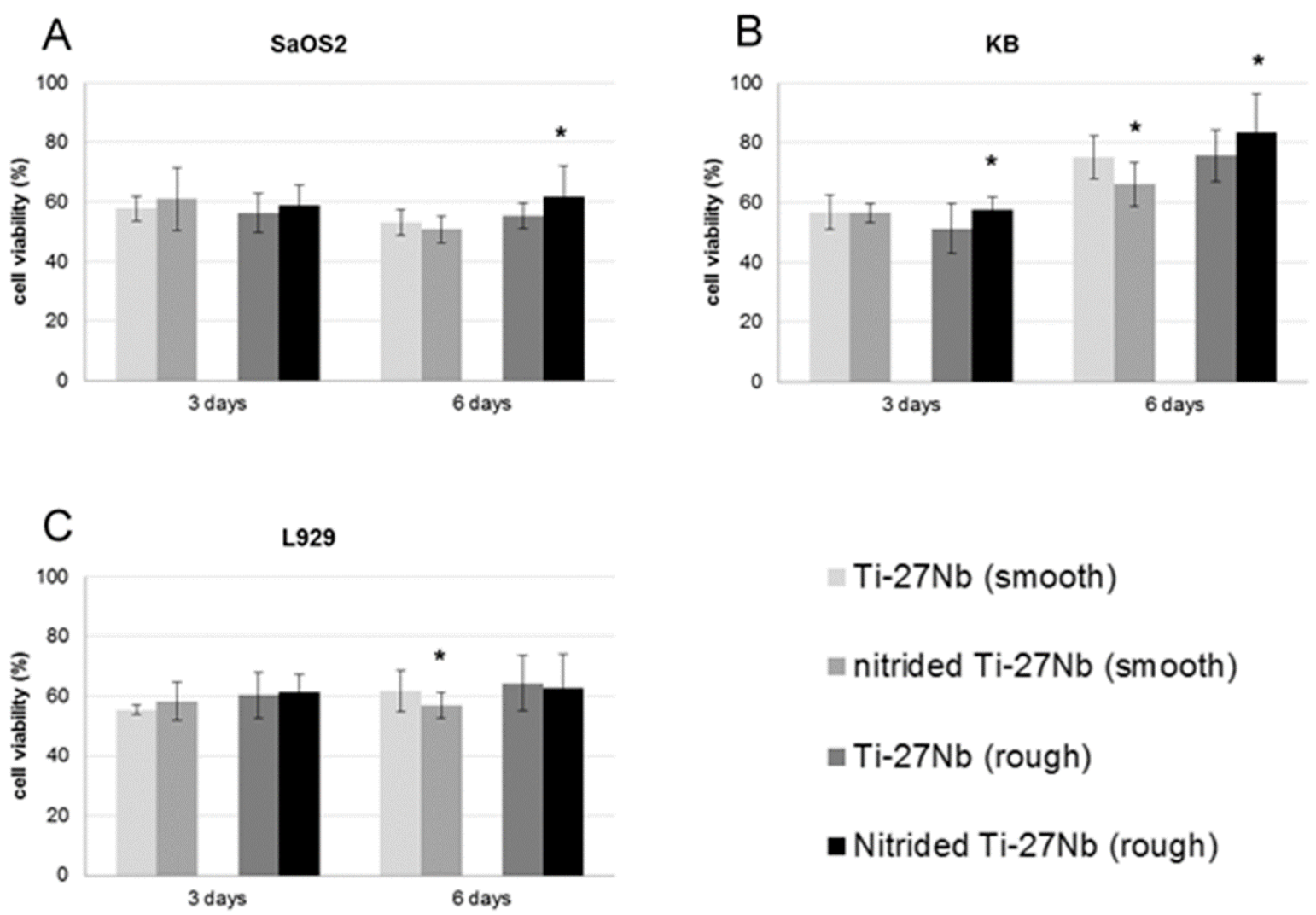

Fig. 6 MTT cell proliferation assays from cell lines cultured on nitrided and non-nitrided Ti27Nb alloy. a SaOS 2 cell line. b KB cell line. c L929 cell line. "Smooth" surfaces $(\mathrm{Ra} \approx 0.05$ $\mu \mathrm{m})$ and "rough" surfaces $(\mathrm{Ra} \approx 0.4 \mu \mathrm{m})$ were both tested. Results are presented as relative proliferation rate compared to control (TCPs). ${ }^{*} \mathrm{p}<0.05$ for cells in contact with non-nitrided Ti27Nb versus cells on the corresponding nitrided samples 